\title{
Asphalt-Fiberglass for Precipitation Catchments
}

\section{LLOYD E. MYERS AND GARY W. FRASIER}

Highlight: Field experience gained in the construction of nine water harvesting catchments since 1962 has shown that field-fabricated asphalt-fiberglass coverings are a dependable means of providing water for livestock on many rangeland areas. Initial construction costs, including site preparation and labor, were less than $\$ 1.25$ per square yard. The asphalt-fiberglass coverings are easy to install, require no sophisticated equipment or skills, and are highly resistant to mechanical damage to wind or animals.

Efficient management of many large rangeland areas requires adequate and dependable livestock water supplies. Sufficient numbers of reliable streams and wells are frequently not available. Ponds built by damming intermittent streams often go dry just when they are needed the most. As a result, ranchers in some areas haul water for their livestock at costs estimated as high as $\$ 38$ per 1,000 gallons (Pearson et al., 1969). Collection of precipitation by artificial catchments could provide water at less cost than hauling. Economic analyses have shown that installation of water harvesting catchments can be a sound investment for the stockman (Workman et al., 1968). Such catchments have been and are being built by governmental agencies to obtain water for livestock.

Many materials and methods have been investigated in attempts to lower the cost of artificial catchments (Myers, 1967). Some of these are promising but need further development. One relatively new material, field-fabricated asphaltfiberglass, appears worthy of immediate consideration by rangeland managers.

The authors are research hydraulic engineers, Agricultural Research Service, U.S. Water Conservation Laboratory, Phoenix, Arizona. At present, the senior author is associate deputy administrator, Western Region, Agricultural Research Service, U.S. Department of Agriculture, Berkeley, California.

The research is a contribution from the Agr. Res. Serv., U.S. Dep. Agr.

The authors acknowledge the assistance and support of the personnel of the San Carlos Apache Indian Tribe; Fort Apache Indian Tribe; Phoenix Area Office, Bureau of Indian Affairs. Department of the Interior; Safford District Office, Bureau of Land Management, Depart ment of the Interior; Southwest Watershed Research Center, Agricultural Research Service, U.S. Dep. Agr .; Hawaiian Commercial and Sugar Co., Puunene, Hawaii, Kukaiau Ranch, Paauilo Hawaii, and the Soil Conservation Service, U.S Dep. Agr., Hawaii Work Units, in installation of the various catchments. Special mention is made of John Griggs, physical science technician, U.S. Water Conservation Laboratory, Phoenix, Arizona, for his contribution in developing the techniques of installation and the evaluation of the materials.

Manuscript received March 19, 1973.
Field experience since 1962 has shown that this material is strong, durable, relatively easy to install, and costs less than sheet steel or butyl rubber.

\section{Performance of}

\section{Asphalt-Fiberglass Catchments}

Nine asphalt-fiberglass catchments, fabricated on site by saturating glass matting with low viscosity asphalt emulsion and then sealing with roofing grade asphalt emulsion, have been constructed since 1967. Five of these were installed in areas of such rugged terrain that use of 4-wheel drive vehicles was necessary to gain access. Two installations were on sites where buried rocks up to 3 feet in diameter could not be removed and no other type of ground cover, including reinforced butyl sheeting, could have been used.

Performance of eight of these catchments has been excellent. Seal coat application was not made on the ninth catchment until 16 months after base coat application, and the seal coat asphalt did not bond satisfactorily to the oxidized base coat. No significant deterioration or mechanical damage by wind or animals has been observed on any of the other catchments. As further evidence of durability, asphalt-fiberglass linings installed in two small reservoirs during 1962 and 1964 are still in reasonably good condition despite an almost total lack of maintenance. Decr have climbed in and out of one of these reservoirs, on $45^{\circ}$ side slopes, with no damage to the lining. Plant growth problems have been limited to two catchments in Hawaii. On one of these catchments, windblown seeds sprouted in three $2-\mathrm{ft}^{2}$ patches of soil on the surface. These were removed in less than $5 \mathrm{~min}$ by hand pulling. On the other catchment, some grass grew through the membrane near the edge because of inadequate soil sterilization before catchment installation.
Since 1967, runoff from a $2,500-\mathrm{ft}^{2}$ asphalt-fiberglass catchment at the Granite Reef Test Site near Mesa, Arizona, has averaged $95 \%$ of the rainfall measured by a standard weighing raingage. This is in an 8 -inch average annual rainfall area where, on the average, $50 \%$ of the total rainfall occurs in storms of less than 0.4 inch. Eighty percent of the total rainfall occurs in storms with rainfall intensities of less than 0.2 inch/hour. Preliminary rainfallrunoff measurements for the catchment on Maui, Hawaii, in a 100-inch average annual rainfall area, indicated good rainfall collection efficiency.

Water running off an asphalt surface can be discolored by oxidized asphalt, particularly in arid regions. The discoloration is directly proportional to the time between rains and inversely proportional to the volume of runoff (Frasier et al, 1970). Discoloration is minimal in high rainfall areas. The discolored water is odorless and tasteless and is readily consumed by cattle.

\section{Construction of Catchments}

Catchments should be installed on a natural slope of 5 to $20 \%$. All vegetation must be cleared to bare soil, and rocks larger than 1-inch diameter should be removed by hand raking. Larger rocks that are partially buried in the soil may be left in place if there are no sharp projections and the rock surface merges smoothly with the soil surface as shown in Figure 1. A low berm or dike is constructed around the perimeter of the catchment, as shown in cross section in Figures 2 and 3 . When water is conveyed from the catchment to the storage structure through a pipe, the berms on the lower side can be made higher to provide short-term water storage on the catchment during high intensity rainfall, thereby reducing the required pipe size. The catchment surface and berms should be compacted with a roller or rubber-tired vehicle to obtain a reasonably smooth surface. To prevent regrowth of vegetation, a suitable soil sterilant should be applied. A trench, at least 5 inches wide and 4 inches deep, is dug on top of the berms around the plot for anchoring the edges of the asphalt-fiberglass cover.

The fiberglass used is fabricated from multiple-length, chopped glass strands 
bonded into a continuous mat 36 to 72 inches wide with a polyester resin sizing which softens when treated with asphalt. Starting on the lower berm of the catchment, the fiberglass is unrolled in a strip transverse to the slope with the lower edge extending into the bottom of the anchor trench. The ends of this fiberglass strip and subsequently laid strips must also extend into the side trenches. Care should be taken to avoid wrinkles. The fiberglass is then coated with $1 / 2$ to $3 / 4$ gal of asphalt emulsion per square yard to saturate the mat and bond it to the underlying soil as shown in Figure 4. Both cationic and anionic emulsions with $60 \%$ solids have proved satisfactory for this base coat. The asphalt can be applied with standard gear pump asphalt spray equipment, or it can be poured on the fiberglass from buckets and spread with soft-bristled industrial floor brooms. After the first fiberglass strip is coated, the next strip is unrolled, overlapping the first strip about 4 inches, and coated with asphalt. This procedure is continued up the slope until the entire catchment is covered. The asphalt emulsion softens the sizing in the matting, allowing it to conform to minor irregularities in the catchment surface within a few hours. Immediately after this base coat is applied, the trenches around the catchment are partially backfilled to prevent wind from damaging the covering before the asphalt sets and hardens.

The seal coat is applied after the base coat has cured and is no longer tacky. During warm, sunny weather, the base coat will cure in 1 or 2 weeks. Light rainfall during the curing will nol ordinarily damage the base coat, but installations should be made during clear

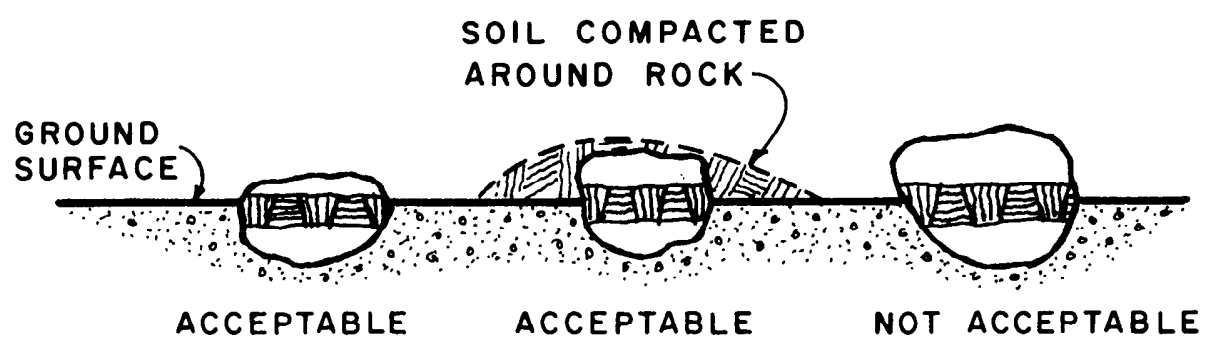

Fig. 1. Illustration of acceptable and nonacceptable buried rocks.

weather if possible. During this time, any "fishmouth" wrinkles in lap joints should be repaired to prevent wind or water entry. This is easily done by cutting the wrinkle lengthwise along the center of the wrinkle, pressing the cut edges flat, placing a fiberglass patch over the wrinkle, and saturating the patch with asphalt emulsion.

The seal coat used is a roofing type asphalt-clay emulsion, with a minimum solids content of $48 \%$, guaranteed for 10 years when applied to a roof at a rate of $1 / 3$ gal per $\mathrm{yd}^{2}$. The seal coat is applied to the fiberglass by spraying or spreading with brooms at a rate of $1 / 3$ to $1 / 2 \mathrm{gal}$ per $\mathrm{yd}^{2}$. Good coverage of lap joints is easier with brooms than with spraying, because the material can be brushed against the laps to fill any small voids. A single, carefully applied seal coat should be adequate for catchment surfaces. Seal coats usually require 2 days of clear, warm weather for curing. Rain can seriously damage uncured seal coats. After the seal coat application, the anchor trenches are completely backfilled.

\section{Maintenance of Catchments}

All water harvesting structures should be visited at least every 6 months to make sure float valves, drinking troughs, water storage systems, and catchment surfaces are maintained in good operating condition. A new seal coat will have to be applied to an asphalt-fiberglass catchment surface every 5 to 10 years, depending on the quality of the material used and the care with which it was applied. Exposure of the white fiberglass will indicate the need for a new seal coat. The catchment should be given a light tack coat of cutback asphalt to ensure bonding of the seal coat to the oxidized surface.

Although properly constructed asphalt-fiberglass catchments are highly resistant to mechanical damage, such damage can occur. Holes in the cover are easily repaired with a patch of fiberglass matting saturated with asphalt emulsion. Large patches should also be given a seal coat. Windblown seeds can germinate and grow in any soil accumulating on the lining surface. The plants and soil should be removed. Penetrating-type plants such as yucca (Yucca sp.) or nut sedge (Carex sp.) not removed or killed during plot preparation can grow up through the

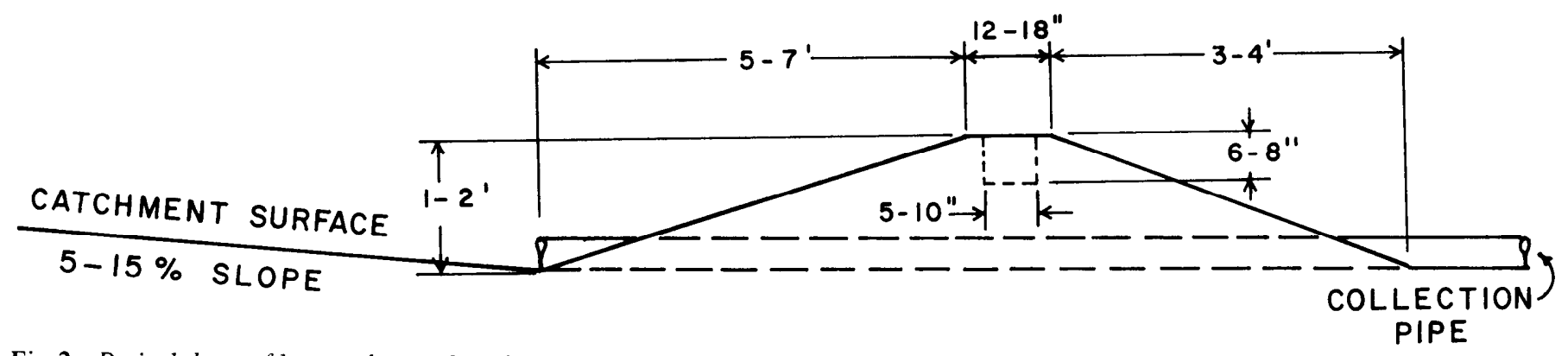

Fig. 2. Desired shape of berm at lower edge of catchment area.

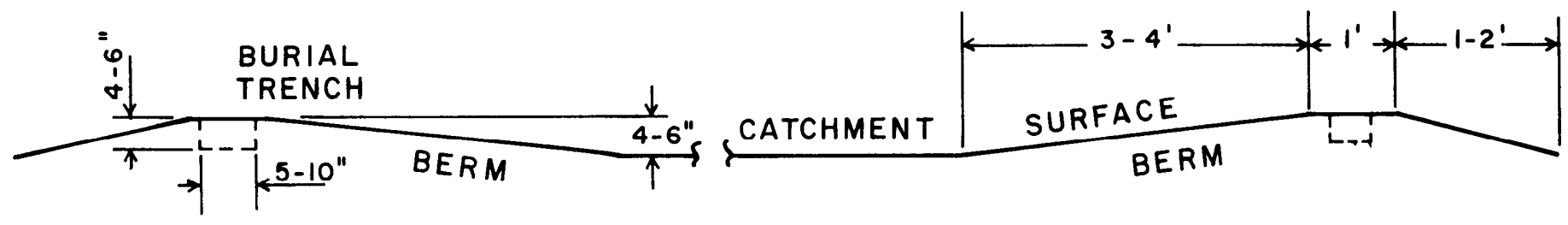

Fig. 3. Berm shape for sides of catchment area. 


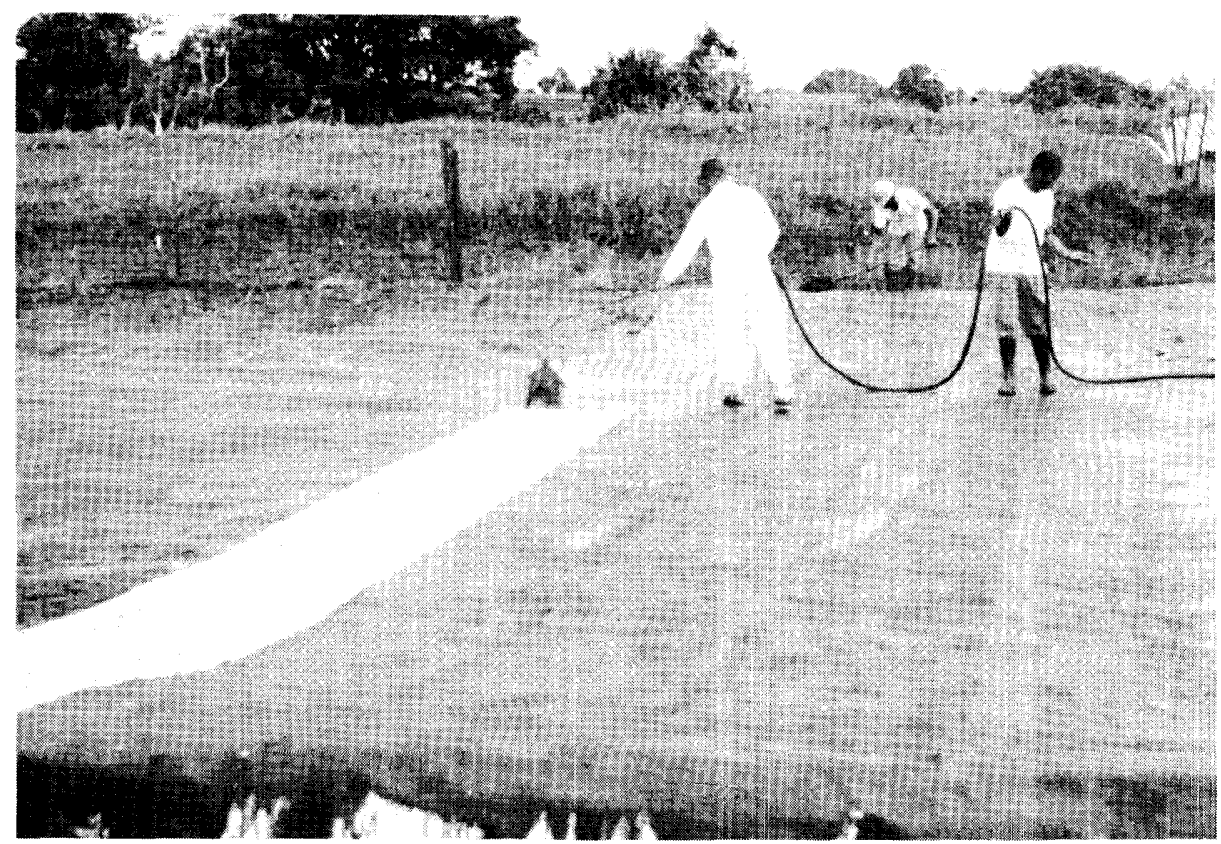

Fig. 4. Laying the fiberglass mat and spraying with asphalt emulsion.

lining. Small plants can be killed by injecting soil sterilant under the lining. Large plants can be removed by cutting the lining, digging them out, and patching the cut area.

\section{Catchment Construction Costs}

Detailed on-site costs for constructing an asphalt-fiberglass catchment on a rough, rocky, brush-covered site near Safford, Arizona, are presented in Table 1. Three men spent 7 hours raking cobbles and debris from the $1,100-\mathrm{yd}^{2}$ site after brush clearing, rough smoothing, and berm construction by a bulldozer. Asphalt emulsion was purchased in 55gallon drums, and the price includes the cost of the drums. Total on-site cost was $\$ 1,342$. A second catchment, installed on a relatively rock $\cdot$ free, naturally smooth site near Tombstone, Arizona, cost less. The site was prepared by a road grader in 1 hour, with no hand raking, and the asphalt was purchased at a bulk lot price in the user's drums. On-site cost of this $1,100-\mathrm{yd}^{2}$ catchment was $\$ 1,050$. Experience in constructing nine asphaltfiberglass catchments indicates that, by making necessary adjustments in costs of materials, equipment, and wages, the information in Table 1 gives a reasonable estimate of probable construction costs. The total cost of the collected water is also dependent upon water storage costs, land costs, and the precipitation (Cooley et al., 1972; Dedrick et al., 1969).

The above costs do not include site selection, surveying, or travel to and from
Table 1. Construction costs for 1,100-y, asphalt-fiberglass catchment.

\begin{tabular}{|c|c|c|}
\hline Item & Cost & \\
\hline \multicolumn{3}{|l|}{ Plot preparation } \\
\hline Bulldozer, $6 \mathrm{hr}$ at $\$ 20$ & $\$ 120$ & \\
\hline Labor, $14 \mathrm{hr}$ at $\$ 3.50$ & 49 & \\
\hline Supervision, $10 \mathrm{hr}$ at $\$ 6$ & 60 & $\$ 2$ \\
\hline \multicolumn{3}{|l|}{ Soil sterilant } \\
\hline Monoborchlorate, & & \\
\hline $150 \mathrm{lb}$ at 14 cents & $\$ 21$ & \\
\hline Labor, $2 \mathrm{hr}$ at $\$ 3.50$ & 7 & \\
\hline Supervision, $1 \mathrm{hr}$ at $\$ 6$ & 6 & $\$$ \\
\hline \multicolumn{3}{|l|}{ Asphalt-fiberglass } \\
\hline \multicolumn{3}{|l|}{ Fiberglass $1 \frac{112 \mathrm{oz}}{}$} \\
\hline \multicolumn{3}{|l|}{ SS-2 emulsion, $550 \mathrm{gal}$} \\
\hline at 30 cents & 165 & \\
\hline Brooms, 3 at $\$ 5$ & 15 & \\
\hline Labor, $20 \mathrm{hr}$ at $\$ 3.50$ & 70 & \\
\hline Supervision, $10 \mathrm{hr}$ at $\$ 6$ & 60 & $\$ 7$. \\
\hline \multicolumn{3}{|l|}{ Seal coat } \\
\hline \multicolumn{3}{|l|}{ Roofing emulsion, } \\
\hline 370 gal at 60 cents & $\$ 222$ & \\
\hline Brooms, 3 at $\$ 5$ & 15 & \\
\hline Labor, $8 \mathrm{hr}$ at $\$ 3.50$ & 28 & \\
\hline Supervision, $4 \mathrm{hr}$ at $\$ 6$ & 24 & $\$ 2 \xi$ \\
\hline Total & & $\$ 1,34$ \\
\hline
\end{tabular}

the job. These costs will be required for any type of catchment construction. Similarly, fencing costs are not included. The Tombstone catchment, installed in July 1971, was not fenced because the asphaltfiberglass is resistant to damage by animal traffic. Observations a year later showed no damage from cattle walking on the catchment surface.

\section{Advantages}

Field experience gained in the construction of nine water harvesting catchments since 1962 has shown that fieldfabricated asphalt-fiberglass coverings are

a dependable means of providing wat for livestock on many rangeland area Catchments can be constructed with th material at an initial cost, including si preparation and labor, of less thi $\$ 1.25 / \mathrm{yd}^{2}$.

The asphalt-fiberglass coverings a easy to install, requiring no sophisticat $\epsilon$ equipment or skills. The material $h$ been successfully installed on surfaces tc rough for more conventional-type catc ment materials. Maintenance on th covering is simple and should require le than 3 man-hours per year between se

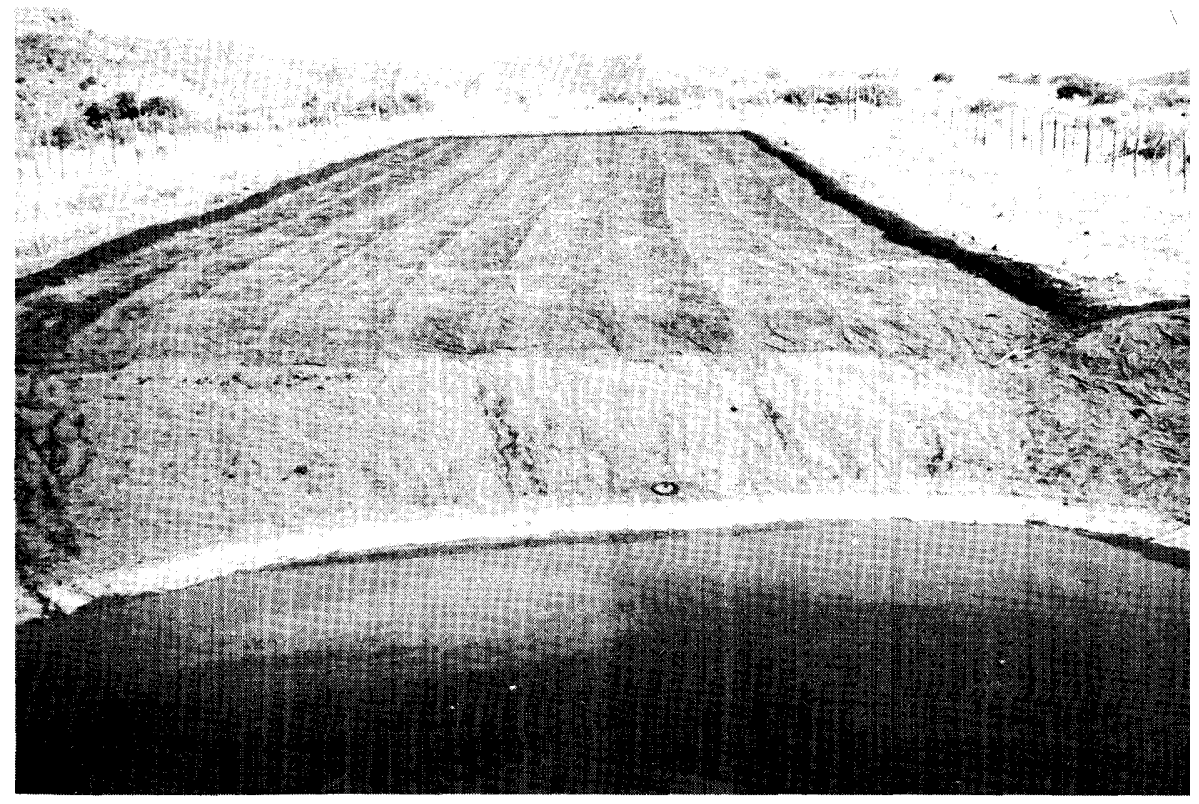

Fig. 5. Completed asphalt-fiberglass lined catchment and reservoir on Fort Apache Indi Reservation. 
coat applications.

The asphalt-fiberglass is flexible during installation, permitting the lining to conform to surface irregularities. After complete curing, the lining becomes semirigid and is highly resistant to damage by wind or animals walking on the surface.

\section{Literature Cited}

Cooley, Keith R., L. E. Myers, and G. W.
Frasier. 1972. Lower cost water harvesting methods. Proc. Symposium on Interdisciplinary Aspects of Watershed Manage. Montana State Univ., Bozeman.

Dedrick, Allen R., and C. W. Lauritzen. 1969. A water storage structure for small systems. Utah Sci. 30(5).

Frasier, Gary W., and Lloyd E. Myers. 1970. Protective spray coatings for water harvesting catchments. Trans. Amer. Soc. Agr. Engrs. 13:292-294.

Myers, Lloyd E. 1967. New water supplies from precipitation harvesting. Intern. Conf. on Water for Peace Proc., Washington, May 1967. Paper No. 391.

Pearson, H. A., D. C. Morrison, and W. K. Wolke. 1969. Trick tanks, water developments for range livestock. J. Range Manage. 22:359-360.

Workman, John P., and Jack F. Hooper. 1968. Preliminary economic evaluation of cattle distribution practices on mountain rangelands. J. Range Manage. 21:301-304. 